LJUBIŠA VASILJEVIĆ

National Museum of Kruševac

Kruševac, Serbia

E-mail: 1jubisa05@gmail.com
Received: October $16^{\text {th }} 2020$

Accepted: December $10^{\text {th }} 2020$

Original research article

903/904:628.1.036.5(497.11 Београд)

COBISS.SR-ID 29191689

https://doi.org/10.18485/arhe_apn.2020.16.6

\title{
ANTIQUE ARCHAEOLOGICAL SITES REGISTERED IN THE VINICITY OF HEALING SPRINGS IN THE AREA OF BELGRADE
}

\begin{abstract}
There are several healing springs in the area encompassed by the territory of the City of Belgrade today. Alongside some of these springs, archaeological sites have been registered. The topic of this paper is the question of whether some of these springs had been known and used by the people of the Antiquity period, including the question of continuity of their exploitation in Prehistory and/or the Middle Ages. The sites presented are: Višnjička Banja, Leštane, Vrčin and Jakovo.
\end{abstract}

KEYWORDS: HEALING SPRINGS, ANTIQUITY, BELGRADE, VIŠNJIČKA BANJA, LEŠTANE, VRČIN, JAKOVO.

Bearing in mind basic theoretical demands, on one hand, as well as the complexity and diversity of the geological structure of the territory of Serbia and the existing structure-geological, geomorphological, hydrogeological, physical-geographical and other circumstances on the other, B. Filipović divided the territory of Serbia into the following six hydrogeological regions:

- Dacian Basin region

- Carpatho-Balkan region

- Serbian crystalline core region

- Šumadija-Kopaonik-Kosovo region

- Dinaric region in Western Serbia

- Pannonian basin region (Филиповић, Б. 2003: 15).

The topic of this paper is archaeological finds (movable or otherwise) discovered in the vicinity of healing springs in the area of Belgrade. We should stress here that only those sites are listed for which we believe that their inhabitants, during the period that interests us, knew about the nearby healing springs and used them. The accent in this paper is placed on the Antiquity period, but the existence of prehistoric and medieval layers will also be mentioned, in order to provide insight into a possible continuity of use of thermal springs.

Within the mentioned division by B. Filipović, the springs from Višnjička Banja, Leštane and Vrčin belong to the Šumadija-Kopaonik-Kosovo region, while the healing springs in Jakovo belong to the Dinaric region in Western Serbia (Васиљевић 2014).

\section{VIŠNJICA AND VIŠNJIČKA BANJA}

Višnjička Banja is a settlement within the area of Višnjica. It was named after a hot spring, originating from the bank of the Dunavac. The tem- 


\begin{tabular}{|c|c|c|}
\hline VIŠNJICA AND & IJIČKA BANJA & \\
\hline Bronze Age & The culture Žuto Brdo & SETTLEMENT \\
\hline Late Iron Age & & Pottery \\
\hline Antiquity & & $\begin{array}{l}\text {-Building } \\
\text {-Votive inscription (?) } \\
\text {-Ring with a carnelian gem } \\
\text {-Coins } \\
\text {-The site of Bela Stena -four } \\
\text { tombs made of bricks }\end{array}$ \\
\hline Early Middle Ages & & $\begin{array}{l}\text { The site of Bela Stena } \\
\text { Byzantine, Sarmatian-Iazygian } \\
\text { and Slav pottery }\end{array}$ \\
\hline Middle Ages & & $\begin{array}{l}\text { There were remains of a round } \\
\text { tower on the bank of the Danube } \\
\text { and a medieval monastery }\end{array}$ \\
\hline
\end{tabular}

perature of the water is $14.4^{\circ} \mathrm{C}$, and its $\mathrm{pH}$ level is 7.5. The water is characterised by the presence of hydrogen sulphide (Филиповић, Б. 2003: 76).

The necropolis from the Bronze Age represents the oldest known trace of settlements on the territory of Višnjica, a discovery provided by $M$. Vasić. There are finds of the fragments of La Tène pottery (ceramics) from this area in Belgrade City Museum. The travel writer Kanitz mentions the existence of the Roman fortress wall. The Roman presence is also confirmed by the votive scripture findings dedicated to an unknown deity (possibly a forgery), antefix, jewelry, and ceramics. The Roman necropilis where four brick built tombs were discovered especially stands out. The Gradina site clearly reveals the existence of the Byzantine fortification, placed on the dominant plateau above the river Danube.

This locality may be identified with the fortification called Octavus, and it was registered by Procopius in his work. The continuity of the process of people forming settlements is confirmed by findings dating from the Great migration period and the Slav period. The remains of the monasteries and most likely a circular tower, which are connected with despot Stefan, also belong to the late medieval period. The writer of these lines described in more detail the mentioned localities
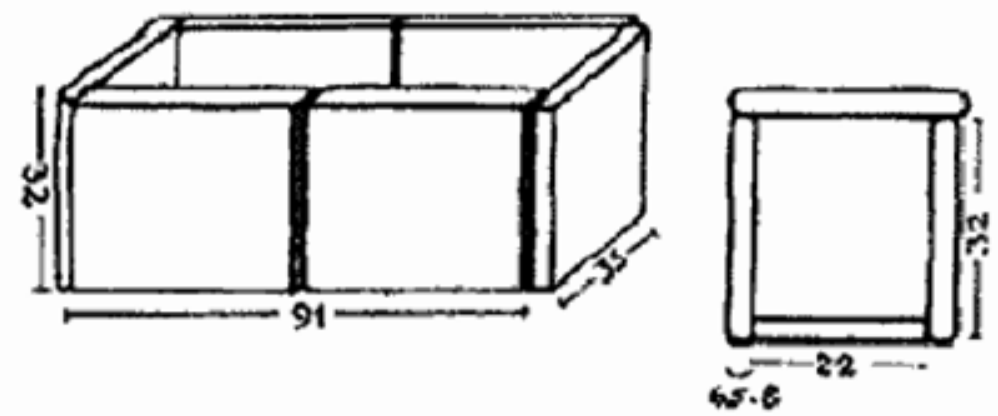

Fig. 1 Construction of a child's tomb from the site of Gradina near Višnjica (according to: Тодоровић, Кондић и Бирташевић 1956, 77, сл. 5). 


\section{LEŠTANE}

\begin{tabular}{|l|l|l|}
\hline $\begin{array}{l}\text { Bronze Age and Older Iron } \\
\text { Age }\end{array}$ & $\begin{array}{l}\text { The site near Bubanj Potok } \\
\text { NECROPOLIS with skele- } \\
\text { tal burials and urns }\end{array}$ & \\
\hline Antiquity & $\begin{array}{l}\text { The site of Zabran } \\
\text { Accidental finding of an } \\
\text { iron PICKAXE }\end{array}$ & \\
\hline Antiquity & $\begin{array}{l}\text { The site near Bubanj Potok } \\
\text { POTTERY }\end{array}$ & \\
\hline
\end{tabular}

in his article dedicated to the exploitation of the healing water springs alongside the Danube limes (Vasiljević 2018: 51-53).

There is no direct evidence on the exploitation of healing springs in the area of Višnjička Banja during Antiquity. On the other hand, there is ample evidence of the tumultuous life and the existence of a Roman settlement, fort, and necropolis in this place, whose development was probably largely influenced by those healing springs.

\section{LEŠTANE}

Leštane is a settlement in the Municipality of Grocka, in the City of Belgrade. There are two healing springs in the area of Leštane. They belong to the nitrogenous water group. The temperature of the water at the source of $\mathrm{L}-1$ is $21^{\circ} \mathrm{C}$, and the $\mathrm{pH}$ value 8 , while the temperature at the spring $\mathrm{L}-2$ reaches $25^{\circ} \mathrm{C}$, and the $\mathrm{pH}$ value is also 8 (Филиповић, Б. 2003: 76).

The findings from Višnjička Banja are represented in this article, as well as the localities in Leštane. In the vicinity of this settlement, at Bubanj Potok, there is evidence of the existence of Bronze and older [earlier] Iron Age necropoli with urns. The fragments of La Tène and Roman ceramics were also found in that locality. The finding of the Antique pickaxe comes from Zabran locality (Vasiljević 2018: 53-54).

Findings from Antiquity are too few for us to be able to talk about a horizon at Leštane. The existence of a prehistoric necropolis would suggest a cult place, which could be linked to healing springs. An answer to questions on the further continuity of this cult place and possible exploitation of healing springs can be provided only by future research.

\section{VRČIN - ZAVOJNIČKA REKA}

Vrčin is a settlement in the Municipality of Grocka, in the City of Belgrade. The temperature of the water is $21-24^{\circ} \mathrm{C}$, and the $\mathrm{pH}$ value 8.5. It belongs to the nitrogenous water group (Филиповић, Б. 2003: 76).

The site of Šuplja Stena in Vrčin is located on the right side of the road Belgrade-Kragujevac, and it is known for being a prehistoric mine (Гарашанин, М. и Гарашанин, Д. 1951: 27).

\section{VRČIN - ZAVOJNIČKA REKA}

\begin{tabular}{|l|l|l|}
\hline Bronze Age & $\begin{array}{l}\text { The site near Bubanj Potok } \\
\text { MINE }\end{array}$ & \\
\hline Bronze Age & $\begin{array}{l}\text { The site near Bubanj Potok } \\
\text { SETTLEMENT }\end{array}$ & \\
\hline
\end{tabular}




\begin{tabular}{|c|c|c|c|}
\hline \multicolumn{4}{|l|}{ JAKOVO } \\
\hline Neolithic & The Vinča culture & $\begin{array}{l}\text { The site of Bršljenak } \\
\text { SETTLEMENT }\end{array}$ & \\
\hline Neolithic/Eneolithic & $\begin{array}{l}\text { The Vinča culture } \\
\text { Horizon I - end of Vinča } \\
\text { B - beginning of Vinča } \\
\text { C } \\
\text { Horizon II - Vinča C/D } \\
\text { Horizon III - } \\
\text { Vinča D }\end{array}$ & $\begin{array}{l}\text { The site of Kormadin } \\
\text { SETTLEMENT }\end{array}$ & $\begin{array}{l}\text { Horizon I (5050-4700 } \\
\text { BC) } \\
\text { Horizon II (4700-4600 } \\
\text { BC) } \\
\text { Horizon III (4600-4400 } \\
(?) \text { BC) }\end{array}$ \\
\hline Bronze Age & & $\begin{array}{l}\text { The site of Kaluđerske } \\
\text { Livade } \\
\text { NECROPOLIS } \\
88 \text { graves with urns } \\
\end{array}$ & \\
\hline Late Bronze Age & The culture of Belegiš & SETTLEMENT & \\
\hline Older Iron Age & Iron Age IV & $\begin{array}{l}\text { The site of Ekonomija } \\
\text { "Sava", a multi-layer } \\
\text { prehistoric SETTLE- } \\
\text { MENT with a SET- } \\
\text { TLING HORIZON from } \\
\text { the Iron Age IV }\end{array}$ & \\
\hline Late Iron Age & & $\begin{array}{l}\text { The site of Ekonomija } \\
\text { "Sava" } \\
\text { THE LA TÈNE HORI- } \\
\text { ZON }\end{array}$ & \\
\hline Antiquity & & $\begin{array}{l}\text { The site of Kaluđerske } \\
\text { Livade } \\
\text { SETTLEMENT }\end{array}$ & $\begin{array}{l}\text { From the } 1^{\text {st }} \text { to the } 4^{\text {th }} \\
\text { century }\end{array}$ \\
\hline Early Middle Ages & & $\begin{array}{l}\text { The site of Kormadin } \\
\text { A Gepid NECROPOLIS }\end{array}$ & $5^{\text {th }}-6^{\text {th }}$ centuries \\
\hline Middle Ages & & $\begin{array}{l}\text { NECROPOLIS } \\
108 \text { graves }\end{array}$ & $\begin{array}{l}\text { From the } 12^{\text {th }} \text { to the } 14^{\text {th }} \\
\text { centuries } \\
\text { The largest number is } \\
\text { from the second half of } \\
\text { the } 13^{\text {th }} \text { and the begin- } \\
\text { ning of the } 14^{\text {th }} \text { century }\end{array}$ \\
\hline Late Middle Ages & & $\begin{array}{l}\text { THE MONASTERY OF } \\
\text { FENEK }\end{array}$ & $15^{\text {th }}-16^{\text {th }}$ centuries \\
\hline
\end{tabular}

Traces of a smaller settlement from the Bronze Age period were registered in the immediate vicinity (Бошковић 1956: 13). Possible connections of these sites and the near-by healing springs are yet to be examined.

\section{JAKOVO}

Jakovo is a settlement in the Municipality of Surčin, in the City of Belgrade. Until 2004, when a new municipality was formed, it belonged to the Municipality of Zemun. Jakovo is located in 
south-eastern Srem, 24 kilometres the south-west of the centre of Belgrade, and 4 kilometres from the bank of the river Sava. The Monastery of Fenek is located in its immediate vicinity.

The temperature of the mineral water in Jakovo is $18.5^{\circ} \mathrm{C}$, and the $\mathrm{pH}$ value is 6.4 . It belongs to the hydrocarbonate waters group, more specifically, to the subclass of sodium waters (Филиповић, Б. 2003: 112-113).

A large number of archaeological sites have been registered in the area of Jakovo. The first archaeological research activities were conducted in this region even before the beginning of World War I.

The oldest layers, determined in the Vinča culture period, belong to prehistoric settlements registered at the sites of Kormadin (a multi-layer site, which encompasses three horizons determined as belonging to the Vinča culture) and Bršljenak. When it comes to the multi-layer site of Kaluđerske Livade, the oldest layer belongs to a necropolis from the Bronze Age Belegiš culture. The settlement located at the site of Ekonomija "Sava" belongs to the Late Bronze Age period. At the same site, the presence of a settlement from the Late Iron Age IV was also registered, as well as a La Tène layer.

The most interesting layer for out topic is the Antiquity horizon at the above-mentioned site of Kaluđerske Livade, where the existence of a longterm Antique settlement was confirmed, inhabited from the first to the fourth centuries. It is assumed that, at the beginning of the new era, there was an autochthonous settlement in this place. The inhabitants of this settlement had been exposed to the Romanisation process, which resulted in a quicker development of the settlement and very intense life in it during the third to the fourth centuries. The chronological sequence of the site in Kupinovo is continued with a Germanic necropolis from the fifth to sixth centuries, discovered at the site of Kormadin. The archaeological picture of the site of Kaluderske Livade is complemented with a medieval necropolis from the $12^{\text {th }}-14^{\text {th }}$ centuries.
The story about the past of Jakovo is completed by the Monastery of Fenek, the founding of which is dated into the second half of the $15^{\text {th }}$ century, according to folklore, although the oldest written mention of the Monastery dates from 1563.

The site of Kormadin (older names: Jakovački Vinogradi and Kurmadin) in Jakovo has been known to the scientific public for a very long time. The first research activities, of smaller range, were performed before the World War I, and the finds were placed in the Archaeological Museum in Zagreb afterwards (Šeper 1952: 25).

Due to vast damage at the site, which occurred between the two world wars as well as during the construction of the modern settlement, the Museum of Zemun performed archaeological rescue excavations in the period from 1956 to 1958.

Kormadin is located on the northern periphery of Jakovo, i.e. on the south-western border of the suburb of Surčin. It consists of a low, spacious hill, bordered by the canal of the river Galovica in the north, and a Roman canal in the south-east. The height of the hill in respect of the surrounding terrain is approximately three metres. Once surrounded with a swamp, but out of the reach of high water, the hill served as a suitable place for settling. Similar favourable conditions had been taken advantage of on the nearby hill of Bršljenak as well, where a Vinča settlement was registered (Јовановић и Глишић 1960: 113).

Research activities have shown that the oldest layer at the site of Kormadin is a Vinča culture settlement. Aside from the prehistoric cultural layer, a Germanic necropolis from the fifth to $6^{\text {th }}$ centuries was also registered. During research conducted in the 1950s, 26 graves were examined (Јовановић и Глишић 1960: 113-142).

Among the finds from Kormadin, especially interesting ones are miniature vessels with tubular spouts. L. Balj defines this type of vessel as "miniature vessels which don't belong to children toys" (Balj 2009: 26). Three small vessels of this type were found at Kormadin (Šeper 1952: T. 2/1, T. 5/6, T. 9/4). 


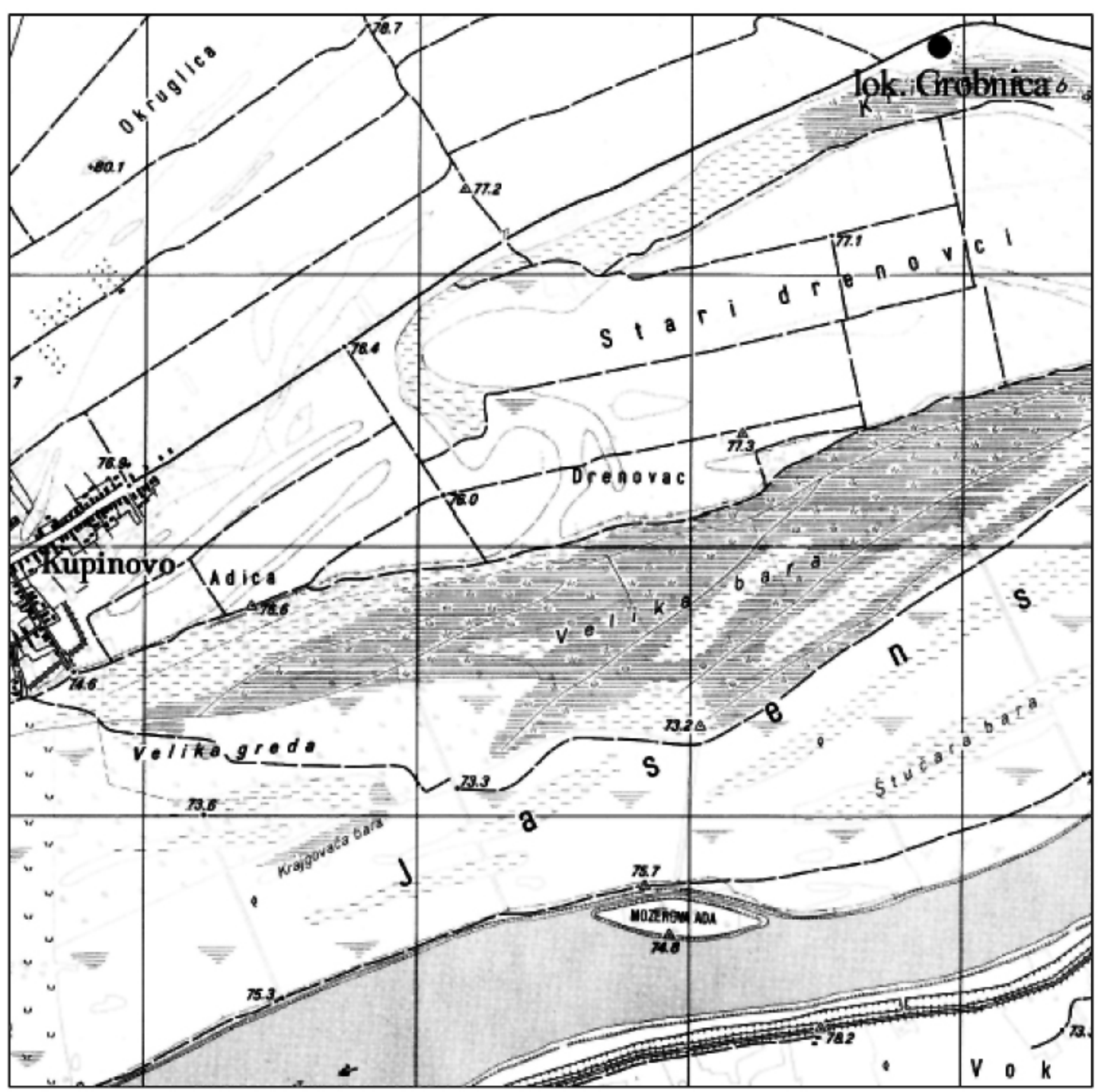

Fig. 2 Detail from a situation plan of the site of Kormadin - excavation campaign in 2008 (according to: Булатовић, Капуран и Стругар 2010: 40).

D. Balen Letunić believes that they had been suitable for feeding children. It is very interesting to note that Schliemann also interpreted similar vessels discovered in Troy in the same manner (Balen Letunić 1982: 72). A different opinion is offered by J. Živković, who believes that the mentioned small vessels had been used for measuring liquid (Živković 2001: 21).

A completely new view on this type of vesselwas given by V. Filipović. According to him, the spout on those miniature vessels was never placed close to the rim, which would mean that the amount of liquid they could receive would be very small and, thus, this type of vesselhad never been used for pouring. The diameters of spout openings, ranging up to 5 millimetres, would also suggest such a conclusion (Filipović, V. 2007: 99).

On the basis of their shape, V. Filipović believes that pipes are in fact the most similar to this type of vessel. The mentioned vessels also have suitable functional traits, such as thick walls, a very narrow opening, and a small spout onto which a longer, wooden pipe could have been attached for smoking. The thickness of walls, com- 
pared to the dimensions of the items, suggests a heat isolation function, as is also the case in modern pipes. On the basis of ethnological and ethno-medial material from these areas, the author concludes that the Vinča culture miniature vessels with a spout had been used for smoking medicinal herbs (Filipović, V. 2007: 99-102).

In order to confirm this assumption, it is necessary to perform a chemical analysis of the traces of substances preserved in those vessels. We should also mention that $\mathrm{L}$. Balj states that no traces of burning had been noted inside vessels of this type from Gomolava, which would have, probably, existed had they been used as pipes, that is to say, if herbs had been burnt in them (Balj 2009: 29).

Especially interesting for our topic is the opinion of M. Živković that the mentioned miniature vessels represent liquid measuring cups. It is, perhaps, too much to assume that the said measuring cups could have been used for measuring the necessary amount of healing water from a nearby spring, but we believe that this possibility also deserves to be noted.

The first finds from the Germanic necropolis at the site of Kormadin were discovered in 1902, when a trustee of the Archaeological Museum in Zagreb, a teacher from Surčin, A. Poturičić, performed minor archaeological excavations of the prehistoric necropolis. Poturičić informed the Museum in Zagreb of the results of his research. It can be seen from his letters that, aside from a significant Eneolithic layer, there were traces of a considerably later necropolis as well, dug into the ruins of the settlement, profiting from its suitable, elevated position. A. Poturičić bears witness to the findings of three skeletons with grave offerings and one without them, oriented along the westeast axis. When it comes to grave offerings, belt buckles were mentioned, as well as iron knives and scissors, and glass and amber pearls. In the three years that followed, excavations continued, headed by Poturičić, and later J. Brunšmid. During the research, more grave offerings were discovered, but they have not been published in detail.
Right until the middle of the $20^{\text {th }}$ century, no attention was given to the medieval findings from Kormadin, even though the site had been damaged on several occasions (Димитријевић 1960: 5).

The exception is a finding discovered while preparing earth for making bricks at the brickyard. On that occasion, six skeletal graves were discovered, oriented along the west-east axis; five of them had grave offerings and one did not. The finds discovered are kept at the Museum of Vojvodina (Димитријевић 1960: 5).

After the founding of the Museum in Zemun in 1955, significantly more attention was given to the site. Since it was determined during a field survey that the site was endangered by earthworks, archaeological rescue excavations began, conducted in three campaigns. The research showed that, in this case, it was probably not a necropolis with continuous rows, but rather an example of the custom of burying the deceased in large groups. D. Dimitrijević mentions that this type of burial can be noted among Germanic tribes from the fifth century, being especially widespread during the sixth and seventh centuries, and gradually ceasing to be practiced in the eighth century. This type of burial reflected the differentiation degree of Germanic society of that period (Димитријевић 1960: 8).

Twenty-six skeletal graves were discovered on the systematically researched part of the terrain, dug directly into the Eneolithic layer. The burials were performed in simple pits, relatively narrow, with rounded ends. Out of the total number of 26 skeletons, eight male individuals were registered, nine female, six children, and three individuals whose sex could not be determined. The position of the skeletons was almost uniform. All the skeletons were laid on their back, stretched out, with legs placed in parallel. The heads of most skeletons were facing forward, but heads were also often turned towards the right shoulder, i.e. towards the north, which led D. Dimitrijević to consider the possibility of this being a remnant of older burial rituals (Димитријевић 1960: 9).

Only two of the researched graves had no 
grave offerings. Those were children graves, marked with numbers 22 and 24. In terms of grave offerings, a sword, spear, arrows, quiver, fibulae, belt buckles, rings, coins, tinder, whorls, combs, glass et al. were registered. On the basis of analysis of research results, D. Dimitrijević concluded that this was a necropolis of the Gepids, settled in the area of Srem during the fifth and the sixth centuries (Димитријевић 1960: 11-44).

We will mention that, on the basis of results obtained through anthropological analyses performed by Ž. Mikić, three out of the total of nineteen analysed skulls from the Germanic necropolis had artificial deformations (Микић 1994: 133).

The research of the necropolis continued in 2008, when, aside from the researched medieval grave, the stratigraphy of the Vinča settlement was additionally and more precisely determined (Булатовић, Капуран и Стругар 2010: 11-42).

During the construction of the by-pass on the highway around Belgrade, in June 1991, an archaeological site located in the place called Kaluđerske Livade was accidentally demolished. The position of the site had not been noted on the map of archaeological sites which the constructor obtained before beginning the works. The site is located in the south-eastern part of Srem that belongs to the city area of Belgrade. It is on the section Dobanovci-Ostružnica, on the left bank of the Sava, between Surčin and Jakovo.

The site is located on the southernmost elevation of the western part of a long loess ridge, oriented along the north-east/south-west axis, running in parallel with the flow of the Sava and surrounded by a swamp. The name of the site probably originates from the fact that, in the period from the $16^{\text {th }}$ to the $19^{\text {th }}$ centuries, this area belonged to the near-by Monastery of Fenek.

Archaeological research, performed on the surface of ca 1 ha, determined the existence of a layer from the Bronze Age period, with 88 graves of incinerated individuals, buried in urns (Петровићb1998: 13-15). I. Bogdanović draws attention to the finding of a dagger, a rare occur- rence in this region (Богдановић 1995/1996: 27).

When it comes to the Antiquity period, part of an Antique settlement was researched, with an uninterrupted continuity in the period from the first up to the fourth century. This continuous existence is explained by its location directly next to the Antique road Singidunum-Sirmium, i.e. Taurunum-Bassianae-Sirmium. Movable and immovable findings bear witness to the existence of a settlement of an autochthonous population from the first century, which went through a Romanisation process after the Roman conquest, after which the life at the settlement continued, with special intensity during the third to fourth centuries (Петровић 1996: 13-31; Црнобрња 1996: 33-36).

The largest number of Antique metal finds were made of bronze and iron. Out of the total of 64 processed finds, thirty were made of bronze, thirty (very corroded and damaged) from iron, one from silver, one was coated with silver, and two were made of lead. Most findings were discovered in the surface layer, created after the removal of humus, and a smaller number were discovered in settlement layers, pits and trenches. Among the metal objects, there are fibulae, bracelets, buckles, rings, keys, medical instruments (tweezers, hooks, probes etc), tools (axes, adzes), as well as fragments of larger objects whose purpose could not be defined with certainty. A total of fifteen fibulae of different types was discovered, dated to the fouth century. B. Petrovic mentions that some of the fibulae that were found represent the first examples of those types discovered in the surroundings of Belgrade. The fibulae had been made in the wider area of the province Pannonia, except for iron ones, which were products of local workshops (Петровић 1996: 13-31).

During the research, sixteen bronze Roman coins were found, dated mostly to the first or second century, up to the fourth century (Црнобрња 1996: 33-36).

The existence of a medieval necropolis was also established, with 108 graves examined. The necropolis is dated to the period from the $12^{\text {th }}$ to 
the $14^{\text {th }}$ centuries, with traces of the most intense burying activities coming from the second half of the the $13^{\text {th }}$, and the beginning of the $14^{\text {th }}$ centuries (Јанковић 2003: 73-120).

The site of Ekonomija "Sava" is located not far from the current flow of the Sava, on an elevated ridge, with a dominant position over the swamp terrain in its surroundings. Trench archaeological excavations, conducted by the Homeland Museum in Zemun in 1959, provided enough data to register the existence of a multi-layer prehistoric settlement. The oldest layer belongs to the Belegiš culture of the Late Bronze Age, followed by a clearly located habitation horizon from the Older [Early] Iron Age, dated to Iron Age IV; the existence of a layer from the La Tène period was also established. The site was registered in 1958, when a hoard of fifty bronze objects - tools, arms [weapons], and various decoration items, was discovered during agricultural works. The field surveys of the terrain showed that the hoard came from the prehistoric settlement, with a surface of ca one square kilometre (Dimitrijević 1959: 60-65; Тасић 1962: 127-130; Тасић 1966: 16).

The Monastery of Fenek is located in the south-eastern part of Donji Srem, on the territory of Jakovo, twenty kilometres from Belgrade. The monastery complex encompasses the church dedicated to Saint Paraskeva, sleeping quarters of the monks, which surround the church on three sides, and a separate chapel, also dedicated to Saint Paraskeva. Even though it does not belong to the group of monasteries of Fruška Gora by its geographic location, Fenek has always been considered as belonging to this group, due to the manner in which it was founded, conditions of historical development, and architectonic shape,. From the very foundation of the monastery, it was an important centre of the cult of Saint Mother Paraskeva, which was especially developed from the beginning of the $15^{\text {th }}$ century in the area of Belgrade and Donji Srem. There are no reliable data on the basis of which an exact date could be determined for when the monastery was built, nor the name of its founder. According to folklore written down by Metropolitan Vikentije Jovanović in his report from December $2^{\text {nd }} 1775$, the Monastery of Fenek, like the monasteries of Krušedol and Hopovo, had been built in the second half of the $15^{\text {th }}$ century by a Serbian Bishop Maksim Branković, with his brother Despot Jovan and their mother Angelina. The oldest historical mention of Fenek, however, comes from 1563 (Божовић 2010: 1).

We believe that it is not a coincidence that the Monastery of Fenek is dedicated to Saint Paraskeva; in fact, we believe that in this case we have an example of a site where the cult of a saint is the continuation of an Antique sacred place of iatric character, linked to the properties of healing waters.

From this overview of the sites, we may assume that thermal springs of the said locations had been known throughout prehistory, Antiquity, and/or Middle Ages. More specific evidence to confirm this assumption can only be provided by future research, on terrain or theoretical.

\section{BIBLIOGRAPHY}

\section{Balen Letunić, D. 1982}

Prethistorijske minijaturne posude - igračke iz Arheološkog muzeja u Zagrebu, Vijesnik Arheološkog muzeja u Zagrebu (t.s.) XV: 69-95.

\section{Balj, L. 2009}

Minijaturne posude vinčanske kulture: dečije igračke ili predmeti druge namene, Рад Музеја Војводине (Rad Muzeja Vojvodine) 51: 23-34.

\section{Богдановић, Д. 1996}

Типологија бодежа раног бронзаног доба у горњем и средњем Подунављу, Рад Музеја Војводине 37-38: 27-42.

(Bogdanović, D. 1996

Tipologija bodeža ranog bronzanog doba u gornjem i srednjem Podunavlju, Rad Muzeja Vojvodine 37-38: 27-42). 
Божовић, А. 2010

Манастир Фенек, Београд: Завод за заштиту споменика културе Града Београда.

(Božović, A. 2010

Manastir Fenek, Beograd: Zavod za zaštitu spomenika kulture Grada Beograda).

Бошковић, Ђ. 1956

Археолошки споменици и налазишта у Србији

- II Централна Србија, Београд: Научна књига.

(Bošković, Đ. 1956

Arheološki spomenici i nalazišta u Srbiji - II

Centralna Srbija, Beograd: Naučna knjiga).

Булатовић, А., Капуран, А. и Стругар, Н. 2010

Неолитски стратум на локалитету Кормадин у Јакову - сондажно ископавање 2008. године, Годишњак Града Београда LVII: 11-42.

(Bulatović, A., Kapuran, A. i Strugar, N. 2010

Neolitski stratum na lokalitetu Kormadin u Jakovu - sondažno iskopavanje 2008. godine, Godišnjak Grada Beograda LVII: 11-42).

\section{Црнобрња, Н. 1996}

Римски новац са локалитета „Калуђерске ливаде“ у Сурчину, Годишњак Града Београда 43: 33-36.

(Crnobrnja, N. 1996

Rimski novac sa lokaliteta „Kaluđerske livade“ $\mathrm{u}$ Surčinu, Godišnjak Grada Beograda 43: 33-36).

Dimitrijević, D. 1959

Jakovo, NOO Surčin, srez Beograd, Lok. Državna ekonomija Sava, Arheološki pregled 1: 60-65.

Димитријевић, Д. 1960

Гепидска некропола Кормадин код Јакова, Гласник Музеја Војводине 9: 5-50.

(Dimitrijević, D. 1960

Gepidska nekropola Kormadin kod Jakova, Glasnik Muzeja Vojvodine 9: 5-50).
Филиповић, Б. 2003

Минералне, термалне и термоминералне воде Србије, Врњачка Бања: Удружење бањских и климатских места, Врњачка Бања и Београд: Институт за хидрогеологију Рударско-геолошког факултета у Београду.

(Filipović, B. 2003

Mineralne, termalne i termomineralne vode Srbije, Vrnjačka Banja: Udruženje banjskih i klimatskih mesta, Vrnjačka Banja i Beograd: Institut za hidrogeologiju Rudarsko-geološkog fakulteta u Beogradu).

Филиповић В. 2007

Минијатурне неолитске посуде са изливником/ сиском и њихова употреба, Архаика I: ур. М.

Лазић, Археолошка збирка Филозофског факултета у Београду, Београд, 95-108.

(Filipović, B. 2007

Minijaturne neolitske posude sa izlivnikom/siskom i njihova upotreba, Arhaika I: ur. M. Lazić, Arheološka zbirka Filozofskog fakulteta u Beogradu, Beograd, 95-108).

\section{Гарашанин, Д. 1954}

Археолошки споменици у Београду и околини, Годишњак Града Београда I: 45-98.

(Garašanin, D. 1954

Arheološki spomenici u Beogradu i okolini, Godišnjak Grada Beograda I: 45-98).

Гарашанин, М. и Гарашанин, Д. 1951

Археолошка налазишта у Србији, Београд: Просвета.

(Garašanin, M. i Garašanin, D. 1951

Arheološka nalazišta u Srbiji, Beograd: Prosveta).

Јанковић, М. 2003

Калуђерске ливаде - средњовековно гробље код Јакова, Гласник Српског археолошког друштва 19: 73-120.

(Janković, M. 2003

Kaluđerske livade - srednjovekovno groblje kod Jakova, Glasnik Srpskog arheološkog društva 19: 73-120). 


\section{Јовановић, Б. и Глишић, Ј. 1960}

Енеолитско насеље на Кормадину код Јакова, Старинар (н. с.) XI: 113-142.

(Jovanović, B. i Glišić, J. 1960

Eneolitsko naselje na Kormadinu kod Jakova, Starinar (n. s.) XI: 113-142.

\section{Крунић, С. 1998}

Нови археолошки налази у Земуну, Београд: Музеј Града Београда.

(Krunić, S. 1998

Novi arheološki nalazi u Zemunu, Beograd: Muzej Grada Beograda).

\section{Микић, Ж. 1994}

Антрополошки осврт на вештачки деформисане лобање из периода велике сеобе народа, Зборник Народног музеја, археологија (Београд) XV-1: 133-139.

(Mikić, Ž. 1994

Antropološki osvrt na veštački deformisane lobanje iz perioda velike seobe naroda, Zbornik Narodnog muzeja, arheologija (Beograd) XV-1: 133-139).

\section{Петровић, Б. 1996}

Римски метални налази са локалитета „Калуђерске ливаде“ у Сурчину, Годишњак Града Београда 43: 13-31.

(Petrović, B. 1996

Rimski metalni nalazi sa lokaliteta „Kaluđerske livade" u Surčinu, Godišnjak Grada Beograda 43: 13-31).

\section{Петровић, Б. 1998}

Нови археолошки налази у Земуну, Београд: Музеј Града Београда.

(Petrović, B. 1998

Novi arheološki nalazi u Zemunu, Beograd: Muzej

Grada Beograda).

\section{Šeper, M. 1952}

Neolitičko naselje na Kormadinu, Arheološki vestnik 3/1: 24-98.

\section{Тасић, Н. 1962}

Насеље култура поља са урнама у источном делу Срема, Рад музеја Војводине 11: 11-15. (Tasić, N. 1962

Naselje kultura polja sa urnama u istočnom delu Srema, Rad muzeja Vojvodine 11: 11-15).

\section{Tacuh, Н. 1966}

Проблем културе поља са урнама у Војводини, Старинар (н. с.) XVII: 15-26.

(Tasić, N. 1966

Problem kulture polja sa urnama u Vojvodini, Starinar (n. s.) XVII: 15-26).

\section{Татић-Ђурић, М. 1964}

Златни налаз из Вишњице, Зборник Народног музеја IV: 185-195.

(Tatić-Đurić, M. 1964

Zlatni nalaz iz Višnjice, Zbornik Narodnog muzeja IV: 185-195).

Тодоровић, Ј., Кондић, В. и Бирташевић М. 1956

Археолошка налазишта у Београду и околини, Годишњак Града Београда III: 75-98.

(Todorović, J., Kondić, V. i Birtašević M. 1956

Arheološka nalazišta u Beogradu i okolini, Godišnjak Grada Beograda III: 75-98).

\section{Васиљевић, Љ. 2014}

Експлоатација и значај термалних извора у римском периоду на територији Србије, Докторска дисертација, Филозофски факултет, Универзитет у Београду.

(Vasiljević, Lj. 2014

Eksploatacija i značaj termalnih izvora u rimskom periodu na teritoriji Srbije, Doktorska disertacija, Filozofski fakultet, Univerzitet u Beogradu).

\section{Vasiljević, Lj. 2018}

Archaeological sites from antiquity registered in the surroundings of hot springs along the Danube limes in Serbia, Archaeology and Science 13 (2017): 47-70. 
Вулић, Н. 1909

Антички споменици наше земље, Гласник Српске краљевске академије 47/40: 109-191. (Vulić, N. 1909

Antički spomenici naše zemlje, Glasnik Srpske kraljevske akademije 47/40: 109-191).

Живковић, J. 2001

Минијатурне посуде са локалитета „Беловоде“ код Петровца на Млави, Viminacivm - Зборник радова Народног музеја у Пожаревиу 12: 5-34. (Živković, J. 2001

Minijaturne posude sa lokaliteta „Belovode“ kod Petrovca na Mlavi, Viminacivm - Zbornik radova Narodnog muzeja u Požarevcu 12: 5-34).

\section{REZIME}

ANTIČKI ARHEOLOŠKI LOKALITETI REGISTROVANI U OKRUŽENJU LEKOVITIH IZVORA NA PROSTORU BEOGRADA

\section{KLJUČNE REČI: ARHEOLOŠKI LOKALITETI, LEKOVITI IZVORI, ANTIKA, BEOGRAD, VIŠN- JIČKA BANJA, LEŠTANE, ZAVOJNIČKA RE- KA-VRČIN, JAKOVO.}

Temu rada predstavljaju arheološki nalazi (pokretni i nepokretni) otkriveni u blizini lekovitih izvora na prostoru Beograda. Isključivo su nabrojani lokaliteti za koje smatramo verovatnim da su njihovi žitelji, tokom perioda koji predstavlja temu proučavanja, poznavali i koristili obližnje lekovite izvore. Naglasak je dat na period antike, ali je navedeno i postojanje praistorijskih i srednjovekovnih slojeva. Na taj način omogućen je uvid u mogućnost postojanja kontinuiteta korišćenja lekovitih izvora.

Predstavljeni su višeslojni arheološki lokaliteti registrovani u Višnjičkoj Banji, Leštanima, Vrčinu (Zavojnička reka) i Jakovu.

Najstariji poznati nalazi iz Višnjičke Banje potiču iz bronzanog i gvozdenog doba. F. Kanic navodi postojanje zidina koje pripisuje rimskom utvrđenju. Zabeleženi su i nalazi rimskih votivnih natpisa (mogući falsifikat) i antefiksa, kao i prstena, novca i keramike iz istog perioda. $\mathrm{Na}$ lokalitetu Gradina nalaze se ostaci vizantijskog utvrđenja, moguće kastela Octavum zabeleženog kod Prokopija. U blizini utvrđenja otkrivene su četiri rimske grobnice, zidane od opeka. Prilikom istraživanja lokaliteta Bela Stena utvrđeno je postojanje peći iz ranog srednjeg veka. U blizini je otkriven i grob sa prilozima u vidu zlatnog nakita iz VI-VII veka. Postoje i nagoveštaji o postojanja srednjovekovnog manastira i kule kružnog oblika.

Moguće je da se na prostoru Leštana nalazilo stanište iz paleolitskog perioda. Kod Bubanj Potoka postojala je nekropola, uništena radovima na izgradnji puta. Pored ostataka ljudskih skeleta i urni, otkriveni su i nalazi iz bronzanog doba, halštata, latena i rimskog perioda. Na lakalitetu Zabran, izvan arheološkog konteksta, otkriven je jedan rimski budak. Dugotrajno korišćenje nekropole n Bubanj Potoku ukazuje na mogućnost postojanja kultnog mesta, čiji bi kontinuitet imao vezu sa postojanjem lekovitih izvora.

Na lokalitetu Šuplja stena u Vrčinu utvrđeno je postojanje praistorijskog rudnika. U neposrednoj blizini rudnika nalazilo se manje naselje iz perioda bronzanog doba. Tek treba utvrditi eventualnu povezanost ovih lokaliteta sa obližnjim lekovitim izvorima.

U ataru Jakova registrovano je više arheoloških lokaliteta. Vinčanskoj kulturi pripadaju naselja na nalazištima Kormadin i Bršljenak. U okviru višeslojnog lokaliteta Kaluđerske livade, najstariji horizont nastao je u okviru belegiške kulture bronzanog doba. Periodu poznog bronzanog doba pripada naselje otkriveno na lokalitetu Ekonomija Sava. $\mathrm{Na}$ istom lokalitetu egzistirala su i naselja u periodima starijeg gvozdenog doba IV i latena.

Za našu temu najznačajnije je antičko naselje na Kaluđerskim livadama, gde je kontinuiran život trajao od I-IV века. Pretpostavlja se da je na ovom mestu, početkom nove ere, postojalo i domorodačko, predrimsko naselje. 
Hronološki sled lokaliteta u Jakovu produžava se germanskom nekropolom iz V-VI veka, delimično istraženoj na lokalitetu Kormadin. Arheološku sliku na lokalitetu Kaluđerske livade dopunjuje srednjovekovna nekropola iz XII-XIV veka. Priču o prošlosti Jakova zaokružuje manastir Fenek, čije podizanje predanje vezuje za drugu polovinu XV veka, mada najstariji pisani pomen manastira datira iz 1563. godine. Manastir Fenek posvežen je Svetoj Petki-Paraskevi, svetiteljki čiji je kult povezan sa izvorima, što može poslužiti kao osnova za mogućnost da su lekovita vrela u Jakovu bila poznata i, u kontinuitetu, poštovana tokom više vremenskih epoha.

Pregled lokaliteta ukazuje na mogućnost da su lekoviti izvori na prostoru današnjeg Beograda bili poznati i korišćeni tokom praistorijskog, antičkog i srednjovekovnog perioda. Konkretnije dokaze za potvrdu ove pretpostavke mogu pružiti jedino buduća istraživanja, terenska i/ili teorijska.

Arheologija i prirodne nauke (Archaeology and Science) is an Open Access Journal. All articles can be downloaded free of charge and used in accordance with the licence Creative Commons - Attribution-NonCommercial-NoDerivs 3.0 Serbia (https://creativecommons.org/licenses/ by-nc-nd/3.0/rs/.

Časopis Arheologija i prirodne nauke je dostupan u režimu otvorenog pristupa. Članci objavljeni u časopisu mogu se besplatno preuzeti sa sajta i koristiti u skladu sa licencom Creative Commons - Autorstvo-Nekomercijalno-Bez prerada 3.0 Srbija (https://creativecommons.org/ licenses/by-nc-nd/3.0/rs/. 